\title{
Duta Versus Ulama
}

Fitriah

Dosen Universitas Sriwijaya

fitriahf222@yahoo.com

\begin{abstract}
Abstrak
Pada era awal tahun 60-an kota Kayuagung yang merupakan ibukota Kabupaten Ogan Komering Ilir (OKI) sangat terkenal dengan julukannya sebagai daerah Alquran karena kota ini banyak sekali melahirkan para qari dan tahfidz. Seiring perkembangannya waktu, julukan tersebut akhirnya mengalami pergeseran. Kayuagung yang tadinya dikenal dengan daerah Alquran yang banyak menciptakan kader-kader hafizh dan qari' berubah image menjadi daerah pengekspor Duta atau bandit luar negeri yang kerjanya tentu saja berhubungan dengan dunia kriminalitas, seperti mencopet, mencuri dan menjambret. Kendati menurut pandangan ajaran agama Islam, tindakan dan perilaku para duta ini tergolong ke dalam perbuatan yang dilarang dan bertentangan dengan aturanaturan yang ada di dalam nash al-Quran dan Hadits, namun kenyataannya dalam realita sosial, banyak fenomena religius yang turut mewarnai dan melengkapi eksistensinya sebagai pelaku kriminal sekaligus sebagai seorang muslim yang taat menjalankan agamanya.
\end{abstract}

Kata Kunci: Respons, Ulama, dan Duta Kayuagung

\begin{abstract}
In the era of the early 60's the city of Kayuagung, which was the capital of the Regency of Ogan Komering Ilir (OKI), was very well known for its nickname as the area of the Koran because the city gave birth to many reciters and tahfidz. Along with the development of time, the nickname finally experienced a shift. Kayuagung, formerly known as the Qur'anic region, which has created hafizh and reciters' cadres, has changed its image to become an exporter of foreign ambassadors or bandits whose work is of course related to the world of crime, such as pickpocketing, stealing and grabbing. Although according to Islamic teachings, the actions and behavior of these ambassadors are classified into acts that are prohibited and contrary to the rules contained in the texts of the Koran and Hadith, but in reality in social reality, many religious phenomena that contribute to and complement its existence as a criminal as well as a Muslim who obeys his religion.
\end{abstract}

Keywords: Responses, Ulama, and Ambassador of Kayuagung

\section{Pendahuluan}

Tersedia Online di http://jurnal.radenfatah.ac.id/index.php/medinate 
Kota Kayuagung adalah sebuah kecamatan defenitif dan sekaligus merupakan ibukota Kabupaten Ogan Komering Ilir (OKI), yang terletak 66 KM dari sebelah tenggara Kota Palembang. Kecamatan ini memiliki luas wilayah \pm $14,543 \mathrm{~km}^{2}$, dengan jumlah penduduk mencapai 58.200 jiwa orang yang tersebar dalam 25 desa/kelurahan yang terdiri dari 12 kelurahan dan 13 desa defenitif.

Kota Kayuagung pada mulanya terdiri dari sembilan marga, yang lebih dikenal dengan sebutan morgesiwe atau sembilan marga yakni Kayuagung, Perigi, Kotanegara (sekarang disebut Kotaraya), Kedaton, Sukadana, Paku, Mangujaya, Sidakersa, dan Jua-Jua.

Mata pencaharian penduduk Kayuagung umumnya adalah pegawai, wirausaha, petani, di samping sebagai pengerajin pada industri kecil dan pertukangan. Mengingat daerah ini tidak banyak didirikan industri-industri besar serta didukung oleh sumber daya alamnya (minyak, gas dan batu bara) yang tidak banyak, maka sebagai ibu kota kabupaten, Kayuagung tidak banyak mengalami perkembangan.

Berdasarkan pada pendataan tahun 2009, tercatat bahwa untuk di Kecamatan Kayuagung terdapat 6.829 rumah tangga miskin dari 58.200 penduduk/jiwa yang ada di Kecamatan Kayuagung. Tidak dipungkiri, dengan keadaan alam yang kurang potensial untuk dijadikan sumber penghidupan bagi masyarakatnya, sehingga Kayuagung tergolong sebagai daerah yang miskin, karena pendapatan yang diperoleh dari penghasilan asli daerahnya masih sangat minim.

Adapun salah satu sumber dana pembangunan daerah Ogan Komering Ilir, berasal dari Anggaran Pendapatan Belanja Daerah (APBD), jika pendapatan daerah tersebut rendah, tentunya pengangguran di daerah tersebut juga tidak banyak mengalami perkembangan. Hal tersebut juga memberikan dampak terhadap kenaikan angka pengangguran. Keadaan tersebut dapat berpengaruh terhadap kehidupan sosial masyarakat Kayuagung. Ini tentunya sangat relevan sekali dengan apa yang dikatakan oleh seorang pakar ekonomi dari Amerika (Samuelson dan W. D. Nordaus 1994, hal. 288-289) bahwa: "Tingkat pengangguran tinggi, sumber daya terbuang percuma dan pendapatan masyarakat berkurang. Dalam masa-masa seperti itu tekanan-tekanan ekonomi menjalar ke mana-mana sehingga mempengaruhi emosi masyarakat maupun kehidupan rumah tangga”.

Inilah salah satu bentuk emosi masyarakat dalam kehidupan sehari-hari menurut Samuelson, yaitu rasa putus asa karena menghadapi situasi ekonomi yang sulit, hal tersebut dapat memberikan reaksi munculnya berbagai tindakan kriminal, seperti mencuri, merampok, dan bentuk kejahatan-kejahatan lainnya. Maka, perwujudan dari emosi atas keputusasaan karena himpitan ekonomi yang diluapkan oleh sebagian besar para pemudanya tersebut adalah dengan merantau 
ke luar negeri, seperti negara Malaysia, Singapura, Thailand, Philipina, Australia, bahkan sampai ke negara-negara Amerika untuk mencari nafkah. Akan tetapi, yang dimaksud dengan "mencari nafkah" di sini bukan dalam artian ikut menjadi seorang TKI (Tenaga Kerja Indonesia) secara legal yang bekerja di pabrik-pabrik, perkebunan, atau pembantu rumah tangga (PRT), melainkan mencari nafkah sebagai bandit di luar negeri atau dalam bahasa Kayuagungnya lebih akrab dikenal dengan sebutan Duta, yang tentunya pekerjaan tersebut erat berhubungannya dengan dunia kriminalitas, seperti mencopet, mencuri, ataupun dengan menjambret.

Dengan keadaan demikian, tidak mengherankan kalau masyarakat Kayuagung hingga saat ini, masih banyak yang pergi merantau guna mencari nafkah bagi keluarganya, hal ini tidak terlepas kaitannya terhadap dorongan naluri sebagai manusia untuk mempertahankan hidup, dorongan usaha untuk mencari makan dan dorongan untuk bergaul (Koentjaraningrat 1990, hal. 110). Tentunya, apapun motif seseorang untuk melakukan tindakan kriminal, tiada lain adalah untuk memenuhi kebutuhan hidupnya, termasuk kaitannya dalam hal ini adalah, dengan menjadi seorang duta.

Selanjutnya, berbicara mengenai persoalan di atas, ajaran Islam sejatinya telah memerintahkan manusia untuk mencari nafkah dan memperoleh rezeki yang halal lagi baik dengan cara-cara yang telah dibenarkan secara syar'i. Hal ini sesuai dengan firman Allah SWT yang berbunyi:

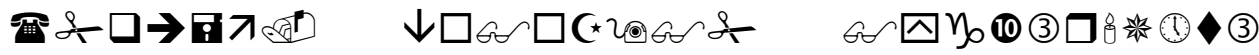

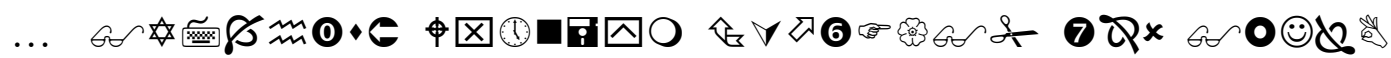

Artinya: "Wahai sekalian manusia, makanlah dari apa yang ada di bumi yang halal lagi baik..." (QS. Al-Baqarah/2:168).

Seruan untuk mencari rezeki yang halal dan dengan cara-cara yang halal dalam ayat tersebut, merupakan perintah wajib yang harus diimplementasikan oleh setiap muslim dalam kehidupan sosialnya. Sebab, setiap pekerjaan yang dilakukan, bermanfaat untuk memelihara martabat dan kehormatan manusia. Dengan kata lain, seseorang akan terangkat derajatnya karena pekerjaan yang dilakukannya, begitu pula sebaliknya ia juga akan terhina dengan pekerjaannya tersebut.

Kendati menurut pandangan ajaran agama Islam, tindakan dan perilaku para duta ini tergolong ke dalam perbuatan yang dilarang dan bertentangan dengan aturan-aturan yang ada di dalam nash al-Quran dan Hadits, namun kenyataannya dalam realita sosial, banyak fenomena religius yang turut mewarnai dan melengkapi eksistensinya sebagai pelaku kriminal sekaligus sebagai seorang 
muslim yang taat menjalankan agamanya. Beberapa di antaranya adalah bagaimana ketika seorang duta akan berangkat ke negara tujuannya, beberapa di antaranya ada yang mengadakan acara yasinan yang diadakan oleh keluarganya dengan mengundang masyarakat kampung atau mendatangi seorang kyai untuk didoakan.

Fenomena di atas tentunya menimbulkan pertanyaan dan asumsi bagi kita terhadap peran dan tugas dari para pengontrol sosial yang dalam hal ini adalah para pemuka agama atau alim ulama. Peran pemuka agama baik sebagai ulama maupun sebagai elite sosial tentu sangat bertentangan dengan profesi yang dilakukan oleh kelompok duta yang berada di dalam masyarakat Kayuagung ini.

Peran ulama sebagai pemuka agama sangat dituntut untuk dapat melakukan pengarahan dan petunjuk kepada masyarakat baik dalam masalahmasalah agama maupun masalah sehari-hari. Secara teologis maupun secara historis-sosiologis ulama merupakan kelompok elit keagaaman yang sangat penting (Zulkifli 1999, hal. 4). Ulama bukan hanya dihormati dan disegani tetapi dalam tatanan masyarakat setiap perkataan ulama dianggap sebagai kebenaran atau acuan yang harus ditaati.

Rentetan panjang cerita mengenai fenomena eksistensi duta kayuagung yang masih aktual hingga saat ini, tentunya mempertanyakan sejauh mana peran dan tugas yang telah dijalankan oleh para alim ulama dalam merespons keeksisan para duta ini.

Dengan berbagai keterbatasan yang ada, maka dalam penelitian ini hanya dilakukan penelitian tentang fenomena Duta Kayuagung dan eksistensinya di tengah-tengah komunitas sosial, serta bagaimana pandangan para alim ulama kecamatan Kayuagung dalam merespons eksistensi dan fenomena Duta Kayuagung tersebut.

Penelitian ini diharapkan menjadi sumbangan pemikiran bagi para tokoh pemegang kekuasaan serta para cendekiawan dan alim ulama dalam mengatasi dan mengantisipasi segala bentuk problematika yang akan menimbulkan konflik SARA. Karena positifnya fenomena Duta Kayuagung yang terjadi di kota Kayuagung ini, tidak pernah menimbulkan konflik apapun. Terlepas apakah dipengaruhi oleh pemahaman keagamaan atau karakteristik dan tipologi yang ada pada masyarakat tersebut.

\section{Kerangka Teori}

Kerangka teori yang digunakan untuk menjawab rumusan masalah dalam penelitian ini di antaranya adalah teori tentang motif kriminalitas, dan Bandit sosial. Ada sebuah pandangan di mana masyarakat menilai dari salah satu segi hukum, bahwa suatu perbuatan merupakan sebuah kejahatan sedangkan dari segi sosiologis (pergaulan) perbuatan itu bukanlah kejahatan, Inilah yang disebut 
kejahatan yuridis. Sebaliknya, suatu tindakan dilihat dari kacamata sosiologis sebagai tindak kejahatan, sedangkan dari segi yuridis, perbuatan itu tidak dapat disebut sebagai tindak kejahatan, hal ini disebut sebagai kejahatan sosiologis (B. Simanjutak 1981, hal. 155).

Kejahatan dapat timbul oleh berbagai faktor, salah satu teori tertua yang dianut oleh para penganut teori Marx mengatakan, bahwa kejahatan timbul karena kemiskinan (B. Simanjutak 1981, hal. 232). Miskinnya masyarakat erat sekali hubungannya dengan masalah rendahnya penghasilan. Kejahatan yang bukan kekerasan memang tali-temali dengan ekonomi. Tetapi untuk menganggap bahwa, mereka berbuat jahat terpaksa karena lapar, adalah juga tidak benar. Dasarnya memang persoalan ekonomi, sebab ketidakpuasan mereka dengan penghasilannya yang sah. Ekonomi dalam arti yang seluas-luasnya memang merupakan potensi kejahatan yang tradisional, lebih-lebih larceny (pencurian) (B. Simanjutak 1981, hal. 233).

Selain itu, sebagai turunan dari kata penjahat ada juga yang disebut dengan istilah Bandit social. Bandit sosial secara universal ditemukan ketika masyarakat didasarkan atas pertanian (dalam ekonomi pertanian), kebanyakan terdiri atas buruh dan petani tak bertanah yang dikuasai, tertindas dan dieksploitasi oleh bangsawan, orang kota, pemerintah, pengacara atau bahkan bank. Mereka ditemukan dalam salah satu dari tiga bentuk utama dari perbanditan sosial yakni; perampok yang terhormat (Robin Hood), pejuang perlawanan (unit grilya) yang primitif, dan para penuntut balas (kaum haiduk) (Bobsbawn 2000, hal. 4).

\section{Metodologi Penelitian}

Metode yang digunakan dalam penelitian ini adalah metode deskriptif analitik yakni meneliti dan mendapatkan informasi sebanyak-banyaknya tentang variabel-variabel yang telah ditentukan. Selain itu, penelitian ini merupakan penelitian kajian lapangan (field research). Sesuai dengan term yang dipakai yaitu "Duta Kayuagung", maka penggalian dan upaya pencarian data-data yang dibutuhkan dalam penelitian ini terpusat di daerah-daerah yang diindikasikan tempat asal keberadaan para duta. Sumber data terbanyak diambil dari informan yang tentunya dari kalangan penduduk asli Kayuagung itu sendiri seperti, ulama atau tokoh agama, pamong adat, dan pejabat pemerintahan yang ada di lokasi penelitian. Selanjutnya data informan juga diambil dari beberapa mantan duta, serta dari pihak aparat kepolisian maupun oknum-oknum pemerintahan Kabupaten Ogan Komering Ilir.

\section{Hasil dan Diskusi}

\section{Eksistensi Duta Kayuagung}

Pada era awal tahun 60-an Kayuagung sangat masyhur dengan julukannya sebagai daerah Alquran. Di mana dari setiap deret rumahnya, suara lantunan ayat-ayat suci 
Alquran senantiasa berkumandang menyambut terbitnya matahari di Shubuh hari serta menghantarkannya lagi pada senja waktu Maghrib. Bersamaan dengan itu juga, di Kayuagung banyak melahirkan para tahfidz dan qari' yang hingga sampai saat ini masih banyak dari mereka yang tersebar ke berbagai daerah untuk menimba ilmu agama secara mendalam, bahkan banyak juga dari meraka yang hingga saat ini masih menetap di Mekkah (Murtadho, wawancara 26 November 2010).

Seiring perkembangannya waktu, julukan tersebut akhirnya mengalami pergeseran. Kayuagung yang tadinya dikenal dengan daerah Alquran, sebagai daerah yang banyak menciptakan kader-kader hafizh dan qari' lambat laun berubah image menjadi daerah pengekspor Duta. Image ini popular, tentunya dibarengi oleh maraknya warga Kayuagung yang melakukan perjalanan ke luar negeri untuk menjadi duta dengan kisah-kisah "keberhasilan"nya yang menghipnotis tumbuhnya duta-duta lainnya yang ada di luar Kayuagung.

Mengenai sejarah bagaimana munculnya kelompok duta pada awalnya, penulis tidak dapat memberikan penjelasan secara mendalam dikarenakan keterbatasan dan kesulitan mendapatkan informasi dari responden yang bersangkutan, namun menurut perkiraan salah satu sesepuh warga asli Kayuagung yang bernama Ishak Mekki, bahwa munculnya duta pertama kali di Kayuagung sekitar akhir 60-an. Pada masa itu Kayuagung merupakan generasi pemula yang memulai karir menjadi duta. Karena pada masa itu peraturan untuk melakukan perjalanan ke luar negeri belum secanggih sekarang, maka banyak dari para pemuda asal Kayuagung yang berangkat mintar ke luar negeri untuk berkarir menjadi duta. Meskipun tingkat pendidikan sebagian mereka yang berangkat sangatlah rendah bahkan ada yang buta huruf, namun hal tersebut tidak menjadi kendala keberhasilan mereka dalam berkarir menjadi duta. Mendengar keberhasilan yang diperoleh oleh para duta asal Kayuagung ini, maka barulah pada tahun 80-an karir menjadi duta ini mulai mendapatkan peminat dari berbagai kabupaten kota di wilayah Sumatera Selatan seperti; Lahat, Lubuk Linggau, Palembang dan lain sebagainya, bahkan juga ada yang berasal dari wilayah di luar provinsi seperti Medan, Jawa, dan lain sebagainya (Mekki, wawancara tanggal 18 Mei 2011).

Meskipun perkiraan tahun ini tidak bisa menjadi patokan awal kemunculan duta, namun setidaknya bila dikaji secara historis pada era tahun 50 - 60-an secara global kondisi di beberapa wilayah di Indonesia pasca pendudukan Jepang, telah mengalami banyak keterpurukan terutama dalam bidang ekonomi, biaya hidup meningkat tajam, di beberapa wilayah banyak terancam kelaparan akibat musim kemarau berkepanjangan dan wabah tikus yang merusak panen serta diperparah oleh maraknya praktik korupsi di semua tingkatan (Oktorino 2009, hal.252-253). Dampak keterpurukan ini tentunya juga dialami oleh sebagian besar masyarakat 
Kayuagung yang notabene-nya juga merupakan bekas wilayah kolonial (Ayib, wawancara 20 Desember 2010).) Kondisi serba sulit pasca perang tersebut memungkinkan bagi beberapa orang berfikir untuk mencari jalan pintas dengan merantau ke luar. Dengan bermodalkan keberanian dan kebiasaan masyarakat Kayuagung yang biasa mintar menggunakan perahu-perahu dagang, tentunya tidak menjadi kesulitan untuk melakukan perjalanan jauh termasuk keluar negeri. Karena secara historis, masyarakat Morgesiwe sejak lama telah mengenal perdagangan dan mereka berdagang dengan memakai perahu dari satu tempat ke tempat lainnya dengan waktu yang cukup lama (mintar). Di masa Muhammad Mansur (1706-1714) menjadi Sultan Palembang di Plaju yaitu di sepanjang benteng sebagai pelabuhan tempat khusus untuk perahu dagang dari masyarakat Kayuagung (Hanafiah 2007, hal.11).

Menarik benang merah dari cerita Mekki dan kondisi sosial masyarakat Kayuagung secara historis, nampaknya cerita-cerita keberhasilan duta Kayuagung yang tersiar ke pelesok wilayah Indonesia bahkan mancanegara, adalah tahun di mana karir duta dan sebutan duta (Keratak) menjadi popular dan mempopulasi sehingga menjadi cikal bakal tumbuh dan menggenerasinya dutaduta lainnya di beberapa pelosok negeri ini dan bukan merupakan tahun awal kemunculan duta. Selanjutnya untuk kajian mengenai tahun awal kemunculan duta serta orang yang menjadi pemula karir duta, menurut penulis perlu ada kajian lebih serius lagi mengingat ada hubungan cukup erat antara kondisi sosial masyarakat dengan latar belakang tradisi mintar masyarakat Kayuagung secara historis.

Pada awalnya negara-negara yang menjadi tujuan yang sering dikunjungi oleh para duta dalam menjalankan operasi, biasanya negara-negara yang merupakan Negara tetangga Indonesia seperti Malaysia, Thailand, Singapura, Berunai, Philipina, Hongkong, Bangkok dan lainnya, bahkan ada juga yang sampai ke Mesir (Afrika), Australia, Paris (Eropa) seperti yang dialami oleh Tarmoz seorang mantan duta yang telah berhasil menjajaki 20 negara (Tarmoz, wawancara tanggal 15 Agustus 20011).

Seiring dengan perkembangan zaman di mana teknologi sudah semakin canggih sehingga mempersempit ruang gerak para duta, dan kini para duta mengalihkan operasinya ke Negara-negara berkembang lainnya seperti Laos, Vietnam dan Kamboja, karena dianggap negara-negara ini relatif mudah dan aman untuk dimasuki, sementara negara-negara sebelumnya telah banyak merekam catatan hitam mereka, sehingga menjadi sulit bagi mereka untuk mengunjunginya lagi, sebagaimana yang dijelaskan oleh Mekki bahwa:

Kemajuan zaman yang semakin maju di mana alat pemantauan sudah semakin canggih mempersulit ruang gerak bagi para duta, khususnya bagi Duta asal Kayuagung, 
selain karena semakin canggihnya tekhnologi, image yang telah disandang bagi pelancong asal Kayuagung sudah sangat buruk di mata internasional sehingga bagi pelancong asal Kayuagung yang akan melakukan perjalanan selalu dicurigai sehingga mempersulit mereka untuk membuat paspor keberangkatan. Kemudian dari situasi perekonomian daerah, khususnya Kayaugung sudah relatif membaik sehingga dari segi angka para duta ini telah mengalami penurunan dan bagi mereka yang telah pensiun menjadi duta mereka beralih profesi menjadi pengusaha, pegawai pemerintahan, da'i dan sebagainya (Mekki, wawancara tanggal 18 Mei 2011).

Mengenai waktu berapa lamanya kepergian para duta tersebut pergi merantau ke luar negeri, biasanya jawaban yang didapat adalah tergantung dari keberhasilan duta tersebut dalam memperoleh uang seperti yang diungkapkan oleh Iskandar (Wawancara, Desember 2010):

Biasanya lamanya mereka merantau tergantung dari situasi, dan hasil yang mereka dapatkan. Kalau situasinya aman dan mereka memperoleh uang, mereka segera pulang, kalaupun mereka baru berangkat dua hari, tiga hari atau seminggu bisa saja pulang kalau berhasil, terkadang juga sampai berbulan-bulan apalagi jika sampai tertangkap dan dipenjara bisa sampai satu atau dua tahun.

Hal ini juga diperkuat dengan pengakuan Udin:

Seorang duta biasanya baru akan pulang ke Kayuagung, kalau dia sudah mendapatkan uang yang banyak dan cukup untuk modal, nafkah untuk keluarga, foya-foya, pesta dan sebagainya, dan yang paling penting adalah untuk pelunasan hutang biaya berangkat sekaligus bunga hutang yang telah ditentukan antara sang duta dengan rintenir atau mantanmantan duta sebelum berangkat dengan jaminan kepulangan mereka.

Dengan demikian masa merantau para duta ke luar negeri tidak bisa dipastikan dalam hitungan hari, bulan ataupun tahun. Seperti yang dijelaskan di atas, para duta baru akan pulang apabila hasil yang diperoleh sudah dianggap mencukupi untuk dibawa ke kampung halamannya. Tentunya hal ini disebabkan banyaknya kebutuhan yang akan dipenuhi dari hasil yang diperoleh nantinya. Selain untuk kebutuhan penafkahan keluarga, modal usaha serta berfoya-foya, yang tak kalah pentingnya adalah untuk pelunasan hutang yang biasanya para duta pinjam dari para rintenir atau mantan-mantan duta yang bersedia 
memberikan hutang dengan bunga yang dijanjikan serta jaminan sekembalinya para duta merantau.

Selanjutnya, dalam hal modus yang sering para duta lakukan kepada para korbannya terbilang sangat rapi dan professional, seperti menjadi agen asuransi kemudian melarikan uang itu, ada yang melakukan hipnotis, ada yang menukarkan tas yang sama dengan milik korban, dan cara lain yang dilakukan tidak dengan terang-terangan mencuri terlebih merampok (Tarmoz, wawancara tanggal 15 Agustus 20011).

Dalam prakteknya, ada dua bentuk operasi yang dilakukan oleh para duta di luar negeri yakni ada yang memang beroperasi sendiri, namun ada juga yang berkelompok antara dua sampai lima orang. Yang beroperasi sendiri jelas berusaha dengan segala trik dan kemampuannya. Namun bagi yang berkelompok, mereka memiliki tugas masing-masing. Ada yang bertugas menggambar suasana (meta; penyebutan dalam masyarakat Kayuagung yang berarti membuat sketsa lokasi target) dan berangkat terlebih dahulu ke lokasi, yang lainnya bertugas mengecoh calon korban dan mengeksekusi (Tarmoz, wawancara tanggal 15 Agustus 20011).

Cara yang mereka lakukan yang tergambarkan diatas yaitu dengan cara yang ideal dan sangat profesional, dimana mereka melakukan ini dengan cara mengatur posisi mengawasi dan posisi eksekusi, tidak jauh berbeda seperti lakon para aktor dikebanyakan film-film laga yang kerap disaksikan di televisi. Pembagian tugas secara professional ini tentunya bertujuan agar operasinya berhasil. Adapun letak keberhasilan operasional kerja mereka terletak pada situasi tempat kejadian yang terlihat aman, dan bukan dari susunan rencana yang terlihat sempurna. Walaupun, rencana yang disusun merupakan rencana yang sangat bagus, tapi kondisi atau situasi tempat kejadian tidak terasa aman, maka rencana tersebut tak berguna.

Situasi wilayah yang terlihat "tidak aman" inilah yang sering membuat mereka gagal dalam melakukan operasi, tapi jika cara ini berhasil mereka bisa dapatkan hasil yang memuaskan, dikarenakan pada cara ini pemilihan korban bukan secara tidak sengaja, tapi sengaja, dengan melihat tampilan fisik, dan barang bawaan korban seperti yang diungkap Tarmoz: "orang-orang yang menjadi target operasi tidak sembarang orang dipilih, biasanya dipilih orangorang yang berpenampilan mewah serta membawa barang berharga dan bermerek, pastinya fisiknya kelihatan layaknya orang kaya"( wawancara tanggal 15 Agustus 20011).

Gambaran operasi kerja diatas menunjukan bahwa pemilihan korban, dilihat dari tampilan fisik korban, dan berapa berharganya barang bawaannya, strategi ini dilakukan dengan rencana yang telah tersusun dari awal. 
Untuk menjadi seorang duta tentunya tidaklah gampang. Di samping harus memiliki pegangan khusus, baik dari kyai maupun dari dukun, menurut Udin, seorang duta juga harus mampu berpenampilan intelek dan perlente. Sebab duta tidak sama dengan penyamun atau seperti kebanyakan penjahat lainnya yang berpenampilan urak-urakan, dan menakutkan. Dengan penampilan yang terkesan rapi tersebut, sehingga sangat sulit menerka profesi yang sebenarnya mereka lakoni.

Selanjutnya Mereka pun pantang beroperasi di negeri sendiri. Ada semacam hukum tidak tertulis yang membuat mereka berpantang seperti itu, mereka menganggap jika mereka beraksi di Indonesia sama saja halnya dengan mereka makan dengan lauk daging tubuh mereka sendiri (Udin, wawancara 11 Oktober 2010). Hal ini juga diperkuat dengan data arsip Kapolsek Kayuagung yang menyatakan ketidakterlibatan para duta dengan aksi-aksi kejahatan yang sering marak di Kayuagung. Dengan demikian operasi yang para duta lakukan, selain punya trik-trik professional juga punya kode etik khusus yang secara tidak langsung harus dipatuhi oleh para duta. Hal ini diterapkan tentunya bukan hanya untuk mendapatkan hasil yang maksimal dan melindungi diri, akan tetapi juga menjaga citra baik para duta di kampung halamannya.

Meski pemerintah tidak pernah mengutus secara resmi para duta ini ke luar negeri untuk tugas khusus, tetap saja mereka ini dikenal sebagai duta. Tidak hanya kiprah dan sepak terjang di dunia hitam yang mendunia, keberadaan duta tidak dapat dipungkiri. Karena hal ini sudah menjadi bagian dari identitas daerah Sumatera Selatan. Dan dari sisi positifnya, eksistensi duta ini juga mendatangkan devisa bagi pemerintah daerah asal mereka, mereka juga bisa disebut sebagai pahlawan devisa.

\section{Faktor Yang Melatarbelakangi Kemunculan Duta}

Setiap gejala-gejala sosial yang terjadi di dalam masyarakat tentu ada hal-hal yang menjadi faktor pendorongnya. Begitu juga dengan fenomena sosial yang terjadi pada masyarakat Kayuagung, terutama yang terkait dengan duta ini. Dari awal munculnya duta sampai saat ini, tentunya ada beragam faktor yang melatarbelakangi seseorang untuk berprofesi menjadi seorang duta. Seiring perkembangan dan kemajuan Kecamatan Kota Kayuagung, faktor-faktor ini juga mengalami pergeseran. Adapun faktor-faktor yang melatarbelakangi seseorang menjadi duta antara lain sebagai berikut:

a. Tekanan ekonomi

Kondisi perekonomian secara umum masyarakat Kayuagung, bahwa dengan keadaan alamnya yang kurang memiliki potensi untuk dijadikan sumber penghidupan bagi masyarakatnya, hingga menjadikan Kayuagung tergolong sebagai daerah yang miskin, karena pendapatan yang diperoleh dari 
penghasilan asli daerahnya sangat minim. Masyarakat yang hidup di Kota Kayuagung hanya mengandalkan sektor perdagangan dan industri kecil, dan umumnya masyarakat di pedesaan lebih bertumpu pada bertani dan nelayan.

Salah satu sumber dana pembangunan daerah Ogan Komering Ilir adalah berasal dari Anggaran Pendapatan Daerah (APBD), jika pendapatan daerah tersebut rendah, tentunya pembangunan di daerah tersebut juga tidak banyak mengalami perkembangan. Hal inilah yang memberikan dampak bagi banyaknya jumlah pengangguran. Keadaan tersebut memberikan berpengaruh yang cukup signifikan terhadap kehidupan sosial masyarakat Kayuagung. Tekanan-tekanan ekonomi yang diakibatkan pengangguran ini mendorong banyaknya masyarakat Kayuagung yang pergi melakukan urbanisasi, baik secara permanen maupun semi permanen di kota-kota besar termasuk ke luar negeri untuk menjadi duta. Hal ini dilakukan karena mereka ingin mencoba mencari kehidupan yang lain yang lebih layak. Kebanyakan mereka yang pergi merantau menjadi duta ini adalah para pemuda yang di daerahnya tidak mempunyai pekerjaan tetap ataupun pengangguran.

Pekerjaan sebagai Duta merupakan pekerjaan yang menurut mereka dapat memberikan keuntungan besar atau dalam hal ini pendapatan yang besar dalam waktu yang sangat cepat. Secara sederhana, mereka melakukan hal tersebut dengan motif ekonomi untuk melangsungkan hidup, memenuhi kebutuhan mereka untuk mendapatkan kepuasan materil tertentu dan tak peduli dengan pandangan masyarakat yang negatif tentang mereka. Menduta adalah sesuatu yang dilakukan dengan cara cepat dan mendapatkan hasil yang banyak, sangat berbeda dengan pekerjaan lainnya.

b. Tekanan Budaya dan Pola Fikir

Selain faktor di atas, ada lagi faktor yang tak kalah pentingnya yang mendorong masyarakatnya untuk pergi merantau yakni adanya tekanan adat. Adat istiadat yang berlaku di dalam masyarakat Kayuagung, seperti halnya dengan upacara-upacara adat dan upacara keagamaan, terkesan sangat mahal jika diukur dengan materi. Di mana upacara-upacara adat tersebut, baik itu upacara kelahiran, khitanan, perkawinan, kematian maupun adat pergaulan muda-mudinya sering dijadikan patokan atau tolok ukur bagi status sosial mereka di dalam masyarakat, sementara itu untuk mengikuti adat tersebut kebanyakan ekonomi masyarkatnya kurang mendukung. Akan tetapi tradisi harus dijalankan oleh manusianya dalam kehidupan bermasyarakat, seperti yang dikemukakan oleh Soekanto (1992: 166), bahwa "karena budaya maupun tradisi merupakan sesuatu turun temurun dari generasi ke generasi tetap hidup terus, meskipun orang-orang yang menjadi anggota masyarakat senantiasa silih berganti, akibat kelahiran dan kematian”. 
Tradisi pergaulan masyarakat Kayuagung yang selalu mengutamakan materi, terutama yang terjadi di kalangan muda-mudinya, hal ini Nampak dengan jelas terhadap gaya hidup sehari-hari masyarakat Kayuagung, tentu saja ini tidak terlepas dari karakteristik masyarakatnya yang selalu ingin hidup senang namun kurang ulet dalam berusaha. Maka tidak sedikit para pemuda tersebut pergi merantau untuk menjadi duta.

Kebudayaan atau tradisi yang mengacu pada materi inilah yang menyebabkan masyarakatnya kurang memberikan perhatian terhadap pemenuhan rohani, sehingga di dalam masyarakat yang demikian dapat dengan mudah terjangkit oleh masalah-masalah sosial, yang nantinya dapat mewarnai nilai-nilai yang berlaku dalam masyarakat tersebut seperti misalnya masalah duta, yang sangat akrab sekali dalam masyarakat Kayuagung.

c. Pemahaman keagamaan yang sempit

Dalam kaitannya dengan penelitian ini, berdasarkan informasi masyarakat bahwa mereka yang berprofesi menjadi duta sebenarnya bukanlah kalangan orang-orang yang buta dengan agama, fakta membuktikan kalau sebagian besar dari mereka adalah orang-orang yang 'tahu' agama. Lebih sederhananya dapat dipahami bahwa mereka mengetahui tentang hukum dan dosa dari pekerjaan yang mereka lakukan. Hanya saja yang menjadi persoalan di sini adalah pemahaman mereka tentang ajaran agama yang dalam konteks ini masih belum mendalam. Ibarat kata, mereka baru tahu kulitnya namun belum mengerti isinya.

Terdapat pemahaman keliru yang berkembang pada kelompok masyarakat yang menjadi duta terkait dengan profesi ini, seperti yang diungkapkan oleh rizal salah seorang mantan duta, mengatakan: "Dalam ajaran Islam dikatakan bahwa harta itu bisa disucikan lewat sedaqoh, walaupun dari hal yang tidak benar. Adapun masalah dosa itu bisa nanti, privasi, masing-masing orang-orang..."(wawancara, 22 November 2010). Tambah Uyainah :"Ada suatu pembenaran untuk pencucian harta dengan cara sedekah sebagai bentuk suatu pertaubatan dan penyucian diri. Dan ini disebabkan oleh belum dipahaminya al-Quran dan Hadits secara baik dan benar" (wawancara, 22 November 2010).

Berangkat dari pemahaman inilah banyak dari anggota masyarakat Kayuagung yang terjerumus ke dalam penyimpangan menjadi bandit/ duta. Bagi mereka yang berhasil dalam usaha perbanditannya tersebut, mereka senantiasa menyumbangkan hasil mereka ke masjid-masjid, panti asuhan, orang-orang yang membutuhkan dan lain sebagainya. Dengan harapan apa yang mereka lakukan ini dapat menyucikan harta dan diri mereka dari dosa tersebut. Dan inilah yang menjadi salah satu faktor masih eksisnya duta hingga saat ini. 


\section{d. Ke-eksisan dan peran seorang duta}

Meskipun dalam karirnya, para duta ini tidak membentuk sebuah organisasi, sehingga mewajibkan adanya pengkaderan oleh para duta senior, namun peran serta dan kemudahan-kemudahan yang diberikan oleh duta senior secara tidak langsung telah melahirkan duta-duta penerusnya. Kemudahan-kemudahan tersebut misalnya memberikan modal berangkat bagi calon duta yang berkeinginan untuk berangkat namun tidak memiliki biaya, dengan jaminan setelah berhasil dan kembalinya sang duta ke kampung halaman, dia harus mengembalikan modal yang dipinjam tersebut sesuai perjanjian yang telah ditentukan antara keduanya (Tarmoz, wawancara tanggal 15 Agustus 20011). Selain itu, para duta senior biasa juga memberikan pelatihan singkat bagi para pemula yang akan berangkat. Pelatihan di sini maksudnya adalah tekhniktekhnik yang biasa dilakukan oleh para duta senior dalam menjalankan operasinya di luar negeri (Iskandar, 20 Desember 2010).

e. Prestise masyarakat terhadap duta

Dahulu, di kalangan masyarakat Kayuagung profesi menjadi duta bukanlah merupakan sebuah aib yang harus ditutupi atau disembunyikan, melainkan profesi menjadi duta adalah profesi yang sangat membanggakan, karena dampak positif dari keberhasilan duta secara tidak langsung akan mengangkat status sosial diri dan keluarga sang duta di tengah masyarakat.

Karakteristik masyarakat Kayuagung yang selalu mengukur suatu kedudukan dengan materi telah mempengaruhi keberadaan duta di tengahtengah masyarakat. Kehidupan duta yang termasuk glamor namun toleran terhadap masyarakat sekitar, mendapatkan prestise tersendiri dalam pandangan masyarakat, sehingga banyak para pemuda yang tergiur untuk menjadi duta.

\section{Fenomena Sosial Keagamaan Duta Kayuagung}

Sebagaimana diketahui bahwa profesi menjadi duta bukanlah profesi yang wajar untuk dilakukan, karena selain profesi tersebut sejatinya memang berbahaya, juga karena profesi ini sangat bertentangan dengan semua norma yang berlaku, baik itu norma hukum, norma agama, dan norma adat.

Fenomena eksistensi duta ini, mulai dari proses keberangkatan hingga kepulangannya, banyak terdapat hal-hal yang unik yang mewarnai keeksistesiannya terutama hal yang menyangkut dengan perpaduan antara yang halal dan yang haram atau antara yang hak dan yang bathil. Maksudnya, dari kemasan profesi duta ini, selain seorang menjadi bandit yang tentunya melanggar norma, juga terdapat nilai-nilai agamis yang mereka biasa lakukan di kampung halamannya antara lain seperti:

1. Yasinan dan Doa Sang Kyai 
Menurut wawancara penulis dengan para tokoh masyarakat setempat di antaranya Iskandar dan Saidi, bahwa ketika seorang duta akan berangkat ke negara tujuannya, bagi mereka yang mampu biasanya mereka mengadakan ritual sedekahan yakni ritual khusus yang dilakukan oleh para duta sebelum mereka berangkat menjalankan misinya ke luar negeri. Ritual ini diadakan oleh keluarganya dengan mengundang masyarakat kampung serta perangkat pemerintah setempat seperti RT, Lurah, Camat, bahkan beberapa dari aparat kepolisian juga diundang dalam acara tersebut.

Ritual sedekah ini sama seperti ritual sedekah-sedekah lainnya. Di mana acara ritualnya biasanya tersusun dari pembacaan yasin-an, tahlilan, ceramah agama, doa keselamatan yang dilanjutkan dengan makan bersama (wawancara Saidi, tanggal 29 November 2010).

Adapun tujuan dari penyelenggaraaan ritual sedekahan tersebut adalah agar duta tersebut ketika berada di negeri rantau, dapat meraup hasil atau rezeki yang banyak dan tentunya pulang dalam keadaan selamat. Hal ini dimaksudkan karena ketika seorang duta pulang ke kota asal dengan membawa uang banyak, biasanya mereka juga tidak segan-segan menyumbangkan uangnya untuk membangun desa dan fasilitas umum, seperti membangun masjid, jalan raya, rumah atau menolong orang yang dalam kesulitan dan lain-lain seperti yang telah dikemukan terdahulu.

Namun dalam perkembangannya, seiring dengan berkurangnya warga yang berprofesi menjadi duta di Kayuagung saat ini, ritual ini juga hampir berkurang bahkan sudah jarang terlihat, karena di antara mereka sudah banyak yang mendatangi ulama atau kyai langsung untuk minta didoakan, seperti pengakuan yang diungkapkan oleh salah seorang kyai yang juga pengasuh pesantren:

Iya...saya sering didatangi para duta untuk minta dido'akan, karena anggapan mereka setiap kyai bisa mendo'akan untuk keselamatan seseorang. Kalo orang punya harta ada yang meminta, yang diberikan hartanya. ya kalo ustadz punya do'a, mereka minta dido'akan, ya kita do'akan. Permasalahan dikabulkan atau tidak do'anya itu urusan Allah. (Uyainah ${ }^{1}$, wawancara 1 Januari 2011)

Hal ini selaras seperti yang juga diungkapkan oleh Kasi Pemerintahan Kecamatan Kayuagung (Iskandar, wawancara 20 Desember 2010):

Ketika berangkatnya seorang duta memang ada ritual tapi ritual ini bukan ritual supaya dapat duit banyak, bukan, untuk keselamatan-pergi selamat, pulang pun selamat. Bagi yang mampu, ritual diadakan dengan mengundang keluarga,

\footnotetext{
${ }^{1}$ Mudir Pondok Pesantren Sabilillah
} 
serta masyarakat sekitar, namun bagi yang tidak mampu ada juga yang ke masjid dengan meminta didoakan pada jama'ah masjid yang rutin ikut pengajian setiap malam jum'at.

Dengan demikian keterlibatan para kyai ataupun tokoh-tokoh agama dalam hal ini sangat berperan penting dalam kelancaran proses ritual yang telah menjadi tradisi keberangkatan bagi sebagian duta hingga saat ini.

2. Infak

Bagi sebagian kelompok, para duta dianggap sebagai pahlawan terutama oleh keluarganya sendiri, bahkan menjadi idola dan kebanggan bagi masyarakat setempat. Hal ini terjadi karena sisi positif dari sikap dan perilaku para duta yang sopan dan dermawan. Kesopanan dan kedermawanan para duta, telah merubah image mereka yang dianggap aib bagi sebagian orang, sehingga menjadi sesuatu yang layak untuk dikagumi dan dibanggakan.

Apabila seorang duta pulang dari luar negeri memperoleh uang dalam jumlah yang banyak biasanya di atas nominal dua ratus juta bahkan milyaran rupiah-, biasanya hasil yang mereka peroleh mereka gunakan untuk keperluan sendiri seperti membangun rumah mewah, mobil, kebun, modal usaha dan lainnya. Selain itu, mereka juga menyumbangkan dan menginfakkan hasil yang mereka peroleh untuk membangun desa dan fasilitas umum, seperti membangun masjid, jalan raya, rumah atau menolong orang yang dalam kesulitan dan lain sebagainya.

Berdasarkan wawancara penulis dengan salah seorang mantan duta yang saat ini telah insyaf dan telah mengabdikan diri sebagai pendakwah atau da'i mengatakan bahwa:

Sejauh ini para duta tidak pernah mengalami kesulitan untuk menyumbangkan hasil yang mereka peroleh dari profesinya sebagai duta, meskipun pihak yang diberikan sumbangan ini tahu betul dana yang disumbangkan tersebut diperoleh dari hasil men-duta, akan tetapi mereka tidak pernah menolak ataupun mengembalikan sumbangan tersebut kepada para duta yang telah menyumbangkannya. Sebagai alasannya mereka menerima sumbangan tersebut adalah karena tidak mau menyinggung perasaan duta yang telah memberikan sumbangan tersebut (Udin, wawancara 11 Oktober 2010).

Lebih dari itu, bagi sebagian duta, mereka beranggapan bahwa dengan bantuan atau sumbangan yang mereka berikan akan membersihkan dosa yang telah mereka lakukan terkait dengan profesi mereka menjadi seorang duta, alasan ini merujuk pada Firman Allah SWT., yang berbunyi: 


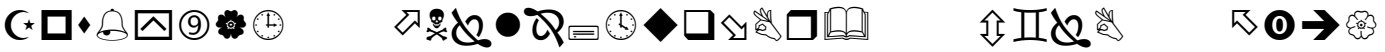

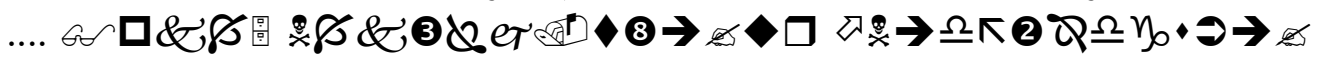

$$
\text { (التوبة /9 (103) }
$$

Artinya: "Ambillah sedekah dari harta-harta mereka, engkau mensucikan mereka dengannya dan engkau membersihkan mereka dengannya"(Q.S. AlTaubah/9:103) $\left(\right.$ Rizal $^{2}$, wawancara, 22 November 2010). Sehingga pada akhirnya transaksi tersebut bisa berjalan tanpa halangan hingga sekarang.

\section{Respons Ulama Terhadap Fenomena Duta}

Profesi menjadi duta dalam masyarakat Kayuagung, sebenarnya bukanlah cerita baru yang mewarnai fenomena penyimpangan sosial di Kota Morgesiwe ini. Kendati demikian, fenomena penyimpangan ini masih tetap popular dan aktual untuk dikaji karena banyak cerita unik yang terdapat dalam balutan profesi ini sebagaimana telah disebutkan pada bab sebelumnya.

Meskipun stempel kota bandit telah disandang oleh daerah Morgesiwe ini sampai ke negeri jiran, namun seiring dengan perjalanan dan perkembangan zaman, fenomena ini tidak begitu banyak mendapatkan perhatian dari berbagai kalangan, baik pemerintah, tokoh-tokoh masyarakat termasuk ulama dan lainnya yang berusaha untuk memberikan solusi perbaikan, sehingga fenomena men-duta ini masih tetap eksis dengan beragam kisah dan ceritanya sampai saat ini.

Pada umumnya, tingkah laku yang sosiopatik (menyimpang) itu mendapatkan reaksi dari masyarakat, berupa; hukuman, penolakan, segresi (pemisahan atau pengasingan) dan pengucilan. Anggapan ini tentunya bertolak belakang dengan fenomena sosiopatik yang terjadi di Kayuagung yang berkultur Islami dan menjunjung tinggi norma agama, hukum dan adat.

Dalam masyarakat Kayuagung golongan pemuka Agama (Alim Ulama) berada pada strata atas. Golongan ini mempunyai pengaruh yang besar dalam kehidupan sosial masyarakat Kayuagung yang mayoritas penduduknya muslim. Para pemuka agama ini sangat dijunjung tinggi keberadaannya, selain sebagai pemuka agama mereka juga merupakan elite sosial yang berperan sebagai pengayom kehidupan sosial masyarakatnya.

Peran tokoh agama baik sebagai ulama maupun sebagai elite sosial tentu bertentangan dengan profesi yang dilakukan oleh kelompok duta yang berada di dalam masyarakat Kayuagung, sehingga menimbulkan reaksi beragam dari para tokoh agama terhadap profesi duta.

Pada umumnya para ulama sangat menolak dengan berbagai macam kemunkaran, termasuk hal yang terkait dengan profesi duta ini, hal ini terlihat dari dakwah dan pendekatan-pendekatan yang telah mereka lakukan terkait hal ini yang meskipun masih tergolong global sehingga belum banyak menuai hasil.

\footnotetext{
${ }^{2}$ Seorang mantan duta, dalam binaan Pesantren Sabilillah
} 
Meskipun pada prinsipnya para ulama menolak dalam artian tidak membenarkan aksi para duta, namun para ulama dapat menerima kehadiran kelompok duta dalam kehidupan bermasyarakat tersebut dengan berbagai alasan di antaranya mereka menganggap para duta adalah bagian dari masyarakat Kayuagung yang mempunyai fitrah sebagai manusia yang harus dihargai, karena di dalam diri para duta juga memiliki nilai-nilai moralitas yang patut dihargai sebagai contohnya para duta tidak pernah melakukan tindak kriminalitas apapun termasuk aksi men-duta-nya di wilayahnya sendiri yakni Kayuagung bahkan mereka juga ikut berpartisifasi menjaga ketentraman dan keamanan wilayah Kayuagung. Selanjutnya alasan kedua adalah sekalipun para duta ini adalah penjahat, menurut para ulama, para duta tidak boleh dimusuhi ataupun ditolak kehadirannya, karena sebagai ulama inilah tugas pokok mereka untuk menyadarkannya sehingga nantinya mereka dapat berubah profesi sesuai dengan tuntunan agama.

Selanjutnya dari hasil wawancara di atas, maka dapat tergambar tentang hubungan interaksi antara para duta dan tokoh agama di Kayuagung yang terjalin akrab dan cukup baik, hal ini dapat dilihat dari keikutsertaan para duta dalam setiap kegiatan yang berbau agama seperti mengikuti pengajian, shalat berjamaah di masjid dan lain sebagainya. Juga tak kalah pentingnya seperti yang diakui oleh Uyaina, salah seorang tokoh agama di kayuagung adalah kunjungan silaturrahmi para duta kepada para pemuka agama dan permintaan doa selamat oleh para duta yang akan mintar serta pengadaan yasinan dengan mengundang para tokoh agama sebelum keberangkatan mereka ke luar negeri adalah menjadi bukti bahwa telah terjalin hubungan yang harmonis dan simbiosis antara keduanya (yakni antara duta dan tokoh agama).

Terkait dengan sikap ulama yang mau mendoakan dan menghadiri undangan yasinan dari para duta ini, tentunya sangat tidak relevan dengan fungsi seorang alim ulama dalam masyarakat yang mayoritasnya adalah Islam ini. Secara sepintas tentunya orang akan beranggapan bahwa para ulama ini turut mendukung perbuatan duta tersebut, akan tetapi anggapan ini dibantah oleh para tokoh agama dengan dalih bahwa mereka hanya memberikan doa keselamatan sesuai dengan yang dimintakan oleh para duta, karena itulah tugas mereka sebagai alim ulama yakni mendoakan siapapun yang meminta didoakan. Sebagai komitmen mereka selaku ulama yang bertugas menyuruh kepada ma'ruf dan dan mencegah dari kemunkaran adalah mereka senantiasa meyelipkan nasihat supaya sekembali mereka ke kampung halaman mereka bisa beralih profesi dan kembali ke jalan yang benar.

Adapun upaya yang dilakukan oleh para ulama ini selain memberikan nasihat-nasihat kepada para duta dalam rangka menyadarkan mereka supaya kembali ke jalan yang benar, juga melalui pendekatan agama lainnya seperti 
ceramah yang diberikan dalam suatu kesempatan di mana para duta ini dapat mendengarkan, seperti dalam upacara keagamaan (memperingati hari besar Islam) maupun ketika khutbah jum'at.

Dari upaya yang dilakukan oleh para tokoh agama atau ulama ini meskipun tidak semua duta tersebut dapat menanggapi secara langsung dengan merubah tingkah lakunya namun dari reaksi (walau hanya mendengarkan saja) yang diberikan oleh para duta ini membuktikan bahwa para duta tersebut menanggapi nasihat-basihat yang diberikan oleh para ulama. Bahkan dari kelompok duta ini ada yang tergabung dalam kelompok pengajian sendiri yang mengkaji secara khusus tentang al-Quran dan isinya. Tentunya hal yang wajar bila ada seorang duta masih menjalankan perintah agama, ini juga terkait dengan prinsip yang dianut oleh sebagian para duta, bahwa merampok adalah pekerjaan yang berhubungan dengan perut (usaha untuk mempertahankan hidup), sedangkan shalat (keterlibatan dalam kegiatan keagamaan) adalah urusan individu dengan yang di atas (Allah).

Dengan demikian, karena tidak menyoloknya prilaku penyimpangan yang ditampilkan oleh para duta ini di wilayah tempat tinggalnya, maka para ulama tidak pernah melakukan larangan, pembatasan atau diskriminasi pada aspek apapun terhadap para duta. Dan sebagai implementasi dari penerimaan masyarakat terutama tokoh agama terhadap para duta adalah para duta mendapatkan kebebasan penuh dalam menjalankan peranannya sebagai warga masyarakat Kayuagung seperti menjalankan ibadah, menikah, mendapatkan pendidikan untuk dirinya dan keluarganya, mengikuti pengajian, ikut serta dalam perpolitikan, bahkan menjadi pegawai negeri sipil, Lurah, anggota dewan legeslatif dan lain sebagainya.

Para duta juga diberikan kesempatan oleh masyarakat untuk mendonasi segala jenis kegiatan baik itu pembangunan masjid, membantu panti asuhan, menyumbang kegiatan hari-hari besar keagamaan dan lain sebagainya. Sifat sosial dan royal mereka ini mendapatkan prestise tersendiri dari masyarakat, sehingga tak jarang dalam setiap kesempatan masyarakat banyak menyanjung serta mengagumi mereka. Kekaguman ini sebenarnya terbentuk dari karakter dan prinsip hidup masyarakat Kayuagung yang selalu berorientasi kepada materi, sehingga orang tidak lagi memandang apa profesinya, namun lebih kepada materi yang dimilikinya. Dengan demikian menjadi sebagai seorang duta bukanlah aib bagi mereka namun salah satu jalan mendapatkan peran dan status sosial yang tinggi dalam masyarakat.

\section{Penutup}

Respons ulama terhadap fenomena duta Kayuagung dinilai wajar secara sosial. Kendati profesi menjadi duta sangat bertentangan menurut ajaran Islam, namun 
para tokoh agama dapat menerima kehadirannya dengan berbagai alasan. Dalam kehidupan sehari-hari, kelompok duta cukup dekat dengan para tokoh agama. Hal ini dikarenakan terdapat hubungan simbiosisme antara ulama dan duta, yang ditandai dengan adanya patron-client dari ulama terhadap duta, mulai dari awal keberangkatan sang duta ke luar negeri hingga kepulangannya ke kampung halaman, Kendati kedekatan ini merupakan salah satu upaya dari para ulama untuk berdakwah secara persuasif, namun pada akhirnya kedekatan mereka mengkaburkan upaya dakwah sejatinya.

\section{Daftar Pustaka}

Alquran Alkarim, Departemen Agama Republik Indonesia.

BPS Kab. OKI 2010, Kecamatan Kayuagung dalam Angka, 2009/2010, Kayuagung.

Bagian Humas dan Protokol Sekretariat Daerah Kabupaten Ogan Komering Ilir dan BPS Kab. OKI 2008. Profil Kbupaten Ogan Komering Ilir 2008, Kayuagung.

Bonger, W.A. 1982. Pengantar Tentang Kriminologi, Diperbaharui oleh Kempe, TH. G. Terjemahan Koesnoen. PT. Pembangunan, Jakarta.

Departemen Agama R.I 1969. al-Qur'an dan Terjemahannya,

Horihoshi, Hiroko 1987. Kyai dan Perubahan Sosial. Perhimpunan dan Pengembangan Pesantren dan Masyarakat, Jakarta.

Hobsbawn, F.J. 2000. Bandit Sosial, Terjemahan M. Zaki Hussein. Tepok Press, Jakarta

Kartono, Kartini 2005. Patologi Sosial. Jil. 1. PT. Raja Grafindo Persada, Jakarta.

Soekanto, Soerjono dkk t.t. Kriminologi; Suatu Pengantar. Ghalia Indonesia, Jakarta.

2007, Sosiologi; Sebuah Pengantar. PT. Raja Grafindo Persada, Jakarta.

Vold 1979. Idiologi of Crime Problam. Appleton Century Craft Inc, New York.

Zulkifli 1999. Ulama Sumsel, Pemikiaran dan Peranannya dalam Lintasan Sejarah. UNSRI, Palembang.

Tersedia Online di http://jurnal.radenfatah.ac.id/index.php/medinate 